\title{
GOTHIC ELEMENTS AND PSYCHOANALYTIC STUDY \\ IN THE TELL-TALE HEART BY EDGAR ALLAN POE
}

\author{
Adi Yusuf \\ Universitas Pesantren Tinggi Darul Ulum \\ adiyusuf@fbs.unipdu.ac.id
}

\begin{abstract}
Exploring horrifying events and mental disorder experienced by an actor in a fiction can be one of satisfying activities for the view of reader's response. This article would present 'gothic' elements and the Psychoanalytic Criticism in The Tell-tale Heart by Edgar Allan Poe. The short story was chosen because it was guessed that the narrator underwent mental disorder; he did violents acts till he committed murder. The method used in this study is a descriptive qualitative. The results showed that 'gothic' elements found in the story are horror, mystery, and romantic. In addition, the main character gets mental disorder called "schizophrenia". The main character seems to have mental disorder called 'schizophrenia', categorized as "catatonic". The narrator experiences the four stages of halluciations and delusions: conforting, condemning, controlling, and conquering which deal with "delusion", and "hallucination".
\end{abstract}

Keywords: gothic, psychoanalytic criticism, schizophrenia

\section{A. INTRODUCTION}

Exploring horrifying events and mental disorder experienced by an actor in a fiction can be one of satisfying activities for the view of reader's response. This exploration can be frequently found in a gothic novel. "Gothic novel" is a kind of novel which is characterized by "mystery, horror, and the supernatural, often with haunted castles, secret passageways, grisly visions, all the paraphernali of the tale of terror" (Morner and Rausch, 1764: p.93). Furthermore, According to The Oxford Companion to English Literature, gothic fiction is "a mode of narrative fiction dealing with supernatural or horrifying events and generally possessed of a claustrophobic air of oppression or evil" (Birch, Dinah. "Gothic fiction").

Dealing with the evil or terror, there is possibility to link it with the character's psychology in a story, which is then discussed in the area of psychoanalitic criticism. "psychoanalytic criticism refers to literary criticism that uses psychoanalytic theory to analyze reader's responses to literature, to interpret literary works in terms of their authors' psychological conflicts, or to recreate authors' psychic lives from unconscious revelations in their work" (Webster, 1995: p.913). According to Freud cited in Bartol (2002), "human behaviour, including violent behaviour, was the product of "unconscious" forces operating within a person's mind. Freud also felt that early childhood experiences had an extreme impact on adolescent and adult behaviour". Freud, for example, believed that conflicts that happen at various psychosexual stages of development might have an influence on individual's ability to operate normally as an adult. Thus, aggression was a basic (idbased) human impulse which is repressed in welladjusted people who have undergone a normal childhood. However, if the aggressive impulse is uncontrollable, or is repressed to an unusual degree, some aggression can "leak out" of the unconscious and a person can take part in acts of violence.

Besides describing gothic elements, this article would also present the psychology of the narrator 
using the Psychoanalytic Criticism because the mental disorder causing the violent behavior in this short story can be clearly seen. It seems that the narrator in this novel experiences 'violent behavior'; he did violents acts till he committed murder and this is the result of 'unconscious' within his mind. More specifically, the narrator is judged as the patient of "catatonic schizophrenia". Saunders (2007) points out that schizophrenia is a mental disorder or group of disorders characterized by in the following disturbances: "in one's thought (e.g., delusions, hallucinations), in mood (e.g., inappropriate affect), in sense of self and relationship to the external world (e.g., loss of ego boundaries, withdrawal), and in behavior (e.g., bizarre or apparently purposeless behavior); it must cause marked decrease in functioning and be present for at least six months)".

\section{B. RESEARCH METHOD}

This is a descriptive qualitative study. The purposes of this study are to find out 'gothic' elements and try to describe psychology of the narrator in the story based on the psychology criticism. The source of data in this study is a short story written by Edgar Allan Poe The Tell-Tale Heart. The data of this study are quotations in the form of sentences that reveal elements of 'gothic' and psychoanalytic criticism, especially schizophrenia.

\section{DISCUSSION}

The story of The Tell-Tale Heart contains 'gothic'. However, Unlike many other works of gothic fiction, this story does happens in a typical abandoned monastery, haunted house or ominous castle. The setting is mentioned as a dark and shadowy place ("black as pitch with the thick darkness"), but the story probably occurs in a house that is located in an urban area instead of an isolated one. We know this because the neighbors who live near the narrator's house are able to listen to the old man cry out at night and then tried to call the police who later show up at the house. Because the house is so unclearly described, the story made the reader imagine the setting and that makes it all the more frightening thought. A classic element of gothic fiction typically involves a threatening atmosphere and it is very important that this is not just part of the background, but forms a crucial part of the storyline. This article describes 3 elements of gothic which are mainly found in the "The Tell-Tale Heart", they are:

\section{Horror}

There are some notable elements which are presented in "The Tell-Tale Heart" such as being a horror story. The main plot of the whole story is basically killing an old man. The murder is committed through detailed planning and ends by disassembling the old man limb by limb. The horror doesn't finish here. The way of murdering the old man should be fairly noticed too. The narrator kills the man with a bed, crushing him under it. He traps him inside it and waits for several minutes, until no heart beat can be heard. The idea of being concealed inside a bed and suffocating to death is frightening. Nobody I presume would prefer a death like the shown example. Even after that, the murderer tries to conceal the carcass by tearing it apart and putting it under three wooden planks.

This kind of Horror can be seen in these qoutations:

"Yet, for some minutes longer I refrained and stood still. But the beating grew louder, louder! I thought the heart must burst. And now a new anxiety seized me - the sound would be heard by a neighbour! The old man's hour had come! With a loud yell, I threw open the lantern and leaped into the room. He shrieked once - once only. In an instant I dragged him to the floor, and pulled the heavy bed over him. I then smiled gaily, to find the deed so far done. But, for many minutes, the heart beat on with a muffled sound. This, however, did not vex me; it would not be heard through the wall. At length it ceased. The old man was dead. I removed the bed and examined the corpse. Yes, he was stone, stone dead. I placed my hand upon the heart and held it there many minutes. There was no pulsation. He was stone dead. His eye would trouble me no more".

"First of all I dismembered the corpse. I cut off the head and the arms and the legs. Then took up three planks from the flooring of the chamber, and 
deposited all between the scantlings. I then replaced the boards so cleverly, so cunningly, that no human eye - not even his - could have detected any thing wrong."

The above quotations clearly show the aspect of horror, killing the old man - how he kills him and what he does after killing are indeed frightening.

\section{Mystery}

Besides the above horror, the story contains mistery too. This can be observed in the case of murder, scenery, and feeling. Besides, the narrator suddenly and stubbornly states that he is actually not a mad person.

"True! - nervous - very, very dreadfully nervous I had been and am; but why will you say that I am mad? The disease had sharpened my senses - not destroyed - not dulled them. Above all was the sense of hearing acute. I heard all things in the heaven and in the earth. I heard many things in hell. How, then, am I mad?" and "If still you think me mad, you will think so no longer when I describe the wise precautions I took for the concealment of the body. The night waned; and I worked hastily, but in silence".

Also, the narrator tells where he murdered a man. The story starts with a mysterious setting and brings the readers to presume what would happen next. Another point to focus on is that the scenery of this incident is also mysterious as it is obscurely described. The unclear description gives a much more frightening and mysterious feeling. Furthermore, the dark environment in which the incident takes place gives information which is extremely important. The dark is when our eyes turn powerless and humans get dependent on other sources of light as the lantern. The narrator uses a lantern in order that he is able to see in the dark, but it can not help so much. Let's consider when we hold a lantern, the holder is able to visualize everything but the people who see the lantern will of course be unable to recognize us. This makes the existence of concealment. In line with the story, the narrator feels superior to the old man and his eye by holding a lantern as it does not indicate his identity. Concealing one's self may also contribute to mistery.

Concealment can be seen all over "The Tell-Tale Heart." Even from the beginning the narrator tries to hide the fact by assuring that he is not mad. Next, he uses a lantern to hide himself from the view of the old man's eye. The murder is also committed by making the old man choked to death as previously mentioned. Suffocation is one of man's greatest fears.

"I had my head in, and was about to open the lantern, when my thumb slipped upon the tin fastening, and the old man sprang up in bed, crying out - 'Who's there?'

"I resolved to open a little - a very, very little crevice in the lantern. So I opened it - you cannot imagine how stealthily, stealthily - until, at length a simple dim ray"

"I describe the wise precautions I took for the concealment of the body. The night waned; and I worked hastily, but in silence."

This clearly gives a clue to the element of gothic. Finally, the concealment of the dead body is another theme of the mystery explained inside the story. Hiding the corpse makes a mysterious atmosphere. This is important to create a tense feeling for the readers. So we can conclude that the story contains the aspect of Mystery not just creates a theme for the story but it is also necessary for the main purpose of gothic literature, horror.

\section{Romantic}

In addition, the other element found in the story is romantic. In order to define Romantic, the word "Passion" comes to mind. We are often confused by the term romantic and romance as the words are organized similarly. However the differences of these two words should be noted. Schlegel cited in Morner (p. 191) defines Romantic as "literature depicting emotional matter in an imaginative form". The particular characteristics of the literature of romanticism contains "subjectivity" and stresses on "individualism; spontaneity"; without being 
controlled by rules; "solitary life rather than life in society" (p.191). Romantic is basically a mixture of strong feelings such as love or hate. It doesn't necessarily mean love at all times, but if an emotion is expressed strongly and passionately we perceive these emotions to be Romantic. In contrast, romance mainly focuses on the emotion love as beautiful and ravishing. So how is Romantic shown in this story? Apparently the narrator has strong feelings for the old man's eye which is the cause of the murder.

He describes it as an "Evil Eye" and shows his revulsion by saying "I made up my mind to take the life of the old man, and thus rid myself of the eye forever." He can not kill the old man without looking at his eyes. Furthermore, the narrator gets furious at the old man eyes and thinks that the eye has "damned spot". For a normal person's point of view this statement is very perplexing. How could any one commit a murder for hatred of an eye? As we go on strong feelings about the man's eye is splattered along the pages of the story. We can believe that the eye of the old man gave him a sense of vulnerability or weakness. The old man was regarded as the superior for the narrator and the eye was supposed to be the way of intimidating him or making him feel wretched as an inferior person.

Besides the story contains gothic elements, it also raises the psychoanalytic criticism, especially what the narrator experiences. It seems that the narrator in the story gets mental disorder categorized "schizophrenia", more specifically "catatonic". "catatonic schizophrenia" is a form that is characterized by any trouble in psychomotor, which may be noticed obviously from the reduction in contact with the environment and in a sudden way, by very happy and enthusiastic, uncontrollable, and motor activity which is seemingly purposeless, by refusal to instructions or efforts to be moved, or "by maintenance of a rigid posture or of fixed bizarre postures" (Saunders, 2007).

Holmes, 1991; Kendall \& Hammen, 1998 cited in Semiun (2006: pp. 29-31) explain that in catatonic reaction, the sufferer undergoes attitudes between "stupor" (like being anaesthetized) and uproar or consternation. Hallucination and delucion happens in the condition of "stupor". In this stage, the sufferer suddenly moves to the act of uproar or consternation with no signs. He is able to do something aggressively and uncontrollably.

Many of the main character's activities are spontaneous, uncontrollable, and purposeless. These can be seen in the following:

"I arose and argued about trifles, in a high key and with violent gesticulations; but the noise steadily increased. Why would they not be gone? I paced the floor to and fro with heavy strides, as if excited to fury by the observations of the men --but the noise steadily increased. Oh God! what could I do? I foamed --I raved --I swore! I swung the chair upon which I had been sitting, and grated it upon the boards, but the noise arose over all and continually increased."

These narrations are the evidence of the uneasy actions undergone by the narrator. This quotation can be seen in the last paragraph of the short story. The narrator felt bothered by the strange noise that haunted him. He first aroused and acted normal even the noise still existed. In a short time, the narrator became more uneasy. It is considered by his statement telling that he paced to the floor and fro. All of them are uncotrollably done by the main character. His uneasiness got worse when he told that he swung and grated the chair.

It is also stated that hallucination and delucion happen to the sufferer when he or she is in the "stupor" situation. This may trigger a conflict experienced by him i.e. good or evil behaviour (Holmes, 1991; Kendall \& Hammen, 1998 cited in Semiun (2006: p. 30). Concerning hallucination and delucion, Clack, 1962 in Antal-Otong (1995) mentions that there are 4 stages of hallucination and delucion: conforting, condemning, controlling, and conquering. The stages are also experienced by the narrator as follows.

\section{Comforting}

* This stage is related to "mild anxiety". The sufferer gets anxious, lonely, or guilthy and "focuses on relieving anxiety with conforting 
thoughts". This stage can be seen in the following quotation.

* "Yet, for some minutes longer I refrained and stood still".

* Here, previously the narrator hears the heartbeat of the old man. The narrator actually got anxious, but he makes efforts to relieve his anxiety by refraining himself and standing still. This quoted words also show that the anxiety experienced by the narrator is not violent.

\section{Condemning}

* This stage correlates with "moderate anxiety". If anxiety rises, the sufferer is in the "state of listening to hallucination". Here, he turns afraid that other people will hear negative voices, and as a consequences, socially removes. The stage of condemning is shown as folows.

* "But the beating grew louder, louder! I thought the heart must burst. And now a new anxiety seized me - the sound would be heard by a neighbour! The old man's hour had come!"

* It can be clearly seen that the narrator' anxiety increases while thinking that the old man's heartbeat gets louder and louder. And, the narrator is afraid that the voices will be heard by a neighbour.

\section{Controlling}

* Then, this stage parallels with "severe anxiety". In this stage, the sufferer stops trying to fight the voices. The voices gets unlimited power, and the person follows the directions of the voices. The power of unlimited voices can be seen in the quotation below.

* "It grew louder --louder --louder! And still the men chatted pleasantly, and smiled. Was it possible they heard not? Almighty God! -no, no!
* This quotation indicates that the narrator's anxiety gets severe because he thinks that the voice goes louder and louder. This situation may triggers the narrator to act violently when it interweaves with hallucination as described in the next stage.

\section{Conquering}

* The last stage is in line with "panic anxiety". The voices seems to threaten if the sufferer does not follow their commands. In this stage, frequently the hallucination interweaves with delusion. During this stage, the sufferer may commit suicide or behave violently. Here, the voices seems real to the sufferer and may lead him to commit a terror. So, there is a close relationship between hallucination and delusion that trigger a person suffering from schizophrenia to commit a terror as described below.

\section{a. Delusion}

The most common type of delusion or false beliefs are paranoid delusions. There are many symptoms of delusion, one of them is "Overpowering", an intense feeling that as if people were talking about you' http://schizophrenia.com/earlysigns.htm.

In the story, there are some delusions that exist in the narrator's mind. Evidences in the narrator action are exaggerated. However, the exaggeration is also able to indicate the evidence of the mental disorder.

"And now a new anxiety seized me --the sound would be heard by a neighbour!"

This is the quotation in the part where the narrator came into the old man's room. He made sure that he heard a strange sound that he believed that the heartbeat of the old man and it was too loud for him. He accused that the sound was too loud that even the neighbor may be able to hear it. This is considered as the delusion for it only exists in the narrator's mind and is impossible in the reality that heartbeat can be clearly heard "loudly", especially by 
his neighbor, without using a special device to hear the inside part of human body.

"It grew louder --louder --louder! And still the men chatted pleasantly, and smiled. Was it possible they heard not? Almighty God! --no, no! They heard! -they suspected! --they knew! --they were making a mockery of my horror!-this I thought, and this I think."

This is the part when the narrator and the police were having a chat in the room. The narrator felt the heartbeat sound of the late old man was getting louder. He believed that the police also should have heard this sound, but they pretended not to show it, because the narrator thought that they were insulting him. This is considered as the delusion undergone by the narrator. His thought about the police actually are not real considering the activity of the police which was described by the narrator. Normally, when someone heard a strange noise that he or she has not heard before, automaticallhy, he or she would behave unpleasantly.

\section{b. Hallucination}

Hallucinations are as real as any other experience to the person who suffers from schizophrenia. As many as $70 \%$ of the sufferers are able to hear voices, while a few of them have visual hallucinations. One of the examples is Auditory hallucinations that can be either inside the person's head or externally. When external, they sound as clear as an actual voice. Sometimes they come from sources which are not apparent, other times they come from real people who actually say nothing, other times a person will hallucinate

sounds

\section{http://schizophrenia.com/earlysigns.htm.}

In the story, the narrator is able to hear a sound of the old man's heartbeat clearly. Yet, this kind of experience is seldom or impossible to be proved by normal people except with a special device. This can be seen in the following quotations:

"There came to my ears a low, dull, quick sound, such as a watch makes when enveloped in cotton. I knew that sound well, too. It was the beating of the old man's heart"

This quotation is taken when the narrator came to the old man's room. He believed that the sound that he heard clearly came from the heartbeat of the old man. This hallucination came to the mind of the narrator and could not be proved as in reality. No heart beat can be heard by normal people, but using a special device.

"And now at the dead hour of the night, amid the dreadful silence of that old house, so strange a noise as this excited me to uncontrollable terror."

This narration is in the part when the narrator came into the old man's room. Again, He believed that he heard a strange noise that triggered him to commit the terror. This is considered as the hallucination considering that it is impossible that in a dreadful silence house to hear a noise.

"Yet the sound increased --and what could I do? It was a low, dull, quick sound --much such a sound as a watch makes when enveloped in cotton." -This is the same statement repeated as in the end part of the story.

"- but the noise steadily increased"

This short phrase is repeated four times in the last paragraph of the story. This hallucination came into the mind of the narrator. This caused him to believe that the noise, the old man's heart beat, clearly could be heard.

\section{CONCLUSION}

In conclusion, the story of The Tell-Tale Heart above has the aspects of 'gothic', they are horror, mystery, and romantic. In addition, the story raises the psychoanalysis criticism. The main character seems to have mental disorder called 'schizophrenia', more specifically called "catatonic". The narrator experiences the four stages of halluciations and delusions: conforting, condemning, controlling, and conquering which deal with 'delusion', and 'hallucination'

\section{REFERENCES}

Antal-Otong, D. 1995. Psychiatric Nursing. W.B. Saunders Company: USA

Bartol, Curt. 2002. Criminal Behaviour: A Psychological Approach. Upper Saddle River, NJ: Prentice-Hall. 
Birch, Dinah."Gothic fiction." The Oxford Companion to English Literature. : Oxford University Press, 2009. Oxford Reference.

Clack, J. 1962. Nursing Care of the Disoriented Patient. An Interpersonal Technique for Handling Hallucination. In Monograph at the American Nurses Association. 13 Kansas City, MO: American Nurses Associations.

Morner, K. and Rausch, R. .NTC's Dictionary of Literary Terms. . NTC Publishing Group

http://kmlasw.blogspot.com/2013/06/a-literaryanalysis-on-tell-tale-heart.html.

http://broccoliyou2.wordpress.com/2011/06/14/th e-tell-tale-heart-factors-that-build-its-moodand-suspense/.

http://schizophrenia.com/earlysigns.htm.

eNotes: The Tell-tale Heart by Edgar Allan Poe retrieved from http://www.enotes.com/telltale-heart/

Saunders. 2007. Dorland's Medical Dictionary for Health Consumers.an imprint of Elsevier, Inc.

Semiun, Y. 2006. Kesehatan Mental 3. Kanisius: Yogyakarta

Webster, M. 1995. Merriam-Webster's Encyclopedia of Literature. USA: Merriam-Webster, Inc. 